\title{
Rice Husk Ash Selection as Solid Oxide Fuel Cell Sealing Ceramic Material
}

\author{
Gunawan $^{1 *}$, Sulistyo ${ }^{2}$, Iwan Setiawan ${ }^{2}$, Agus Suprayitno ${ }^{1}$ \\ ${ }^{1}$ Faculty of Industrial Technology, Sultan Agung Islamic University, Semarang, Indonesia, \\ ${ }^{2}$ Faculty of Engineering, Diponegoro University, Semarang, Indonesia \\ *Corresponding author: gunawan@unissula.ac.id
}

\begin{abstract}
Various ceramic glass compositions have been designed and tested as Rigid Bonded Sealing in Solid Oxide Fuel Cell (SOFC) applications. The ion of silica dioxide $\left(\mathrm{SiO}_{2}\right)$ synthesized with other oxides as character enhancers. $\mathrm{SiO}_{2}$ can be obtained from mines or from decomposition of living things, one of which is Rice Husk Ash (RHA) as a thermochemical transformation product. Conversion process conditions e.g. (pyrolysis, gasification or combustion) may affect the physical-chemical characteristics of the final product. RHA generally contains approximately $60 \%$ silica $\left(\mathrm{SiO}_{2}\right), 10-40 \%$ carbon and a small portion of other material compositions. In this study, an RHA production process was carried out from Rice Husk (RH) samples from Klaten (R1) and Wonosobo (R2) Central Java. The calcination process was carried out by washing the RH route with Sodium Lauryl Sulfate (SLS) as a surfactant and $0.5 \mathrm{M}$ sulfuric acid $\left(\mathrm{H}_{2} \mathrm{SO}_{4}\right)$ for leaching. The drying process was done with an oven for 24 hours at $110^{\circ} \mathrm{C}$. The production process ended with burning in a muffle furnace at $650^{\circ} \mathrm{C}$ for 2 hours. The characterization of RHA from both samples produced amorphous silica $\left(\mathrm{SiO}_{2}\right)$ with an average particle size of $\mathrm{R} 1=0.217$ and $\mathrm{R} 2=0.268$ $\mu \mathrm{m}$. Both samples were consisted of amorphous silica with purities above $97 \%$. The surface area of silica grains produced after washing RH with sulfuric acid are R1 $=265.73 \mathrm{~m}^{2} / \mathrm{g}$ R2 $=294.37 \mathrm{~m}^{2} / \mathrm{g}$. The average pore diameter of $\mathrm{R} 1$ is $\sim 2.04 \mathrm{~nm}$ and $\mathrm{R} 2$ is $1.89 \mathrm{~nm}$, indicating that the silica produced by R1 is mesoporous while R2 is microporous. Microstructural visualization through SEM strengthens the information of RHA produced. High purity amorphous silica has a large grain surface area. useful as an absorber or supporting catalyst in chemical synthesis. This supports the synthesis of RHAwith other oxides in its production as a seal to the SOFC system.
\end{abstract}

Key words : Seal, SOFC, RHA, Characterization.

\section{INTRODUCTION}

Among fuel cell technologies, Solid Oxide Fuel Cell (SOFC) is the most promising and shows great potential in distributed generator applications due to its strong electrolyte properties, ability to reform gas fuels and high efficiency [1]. SOFC works electrochemically at intermediate temperatures with its basic components of anode, electrolyte, cathode, interconnection and sealant. Each has a special function and is made of ceramic materials that are able to adapt well to extreme operating cycles [2].

Various ceramic glass compositions have been designed and tested as Rigid Bonded Sealing in SOFC applications. The material composition consists of basic composition of silica dioxide $(\mathrm{SiO} 2)$ with other oxides to achieve the desired material performance. Ceramic sealing materials are derived from those developed material using Silica Diocside ( $\mathrm{SiO} 2)$ as a base material. This material is then synthesized with other oxide materials $\left(\mathrm{AlO}_{3}, \mathrm{BaO}, \mathrm{CaO}, \mathrm{MgO}, \mathrm{TiO}_{2}\right.$ and others) as a reinforcement. The material developed must be able to withstand the load cycle temperature and will support the operation for a relatively long time [3-9].

One of the main challenges in implementing solid oxide fuel cells (SOFC) is the development of a suitable sealing material as an air and fuel separator. Several approaches have been used to achieve adherence to the necessary prerequisites, mechanical integrity and stability [10], including rigid seals (no-load applied during operation) and compressive seals(load applied during operation).

Seals are generally used as a gap cover in the cell and chamber (reaction chamber). This seal is usually made of ceramic material which can withstand temperature cycle loads. The CTE must be in accordance with the electrodes material, not easily cracked, and have high resistivity [11]. Rigid seals make effective bonds on the surface and offer advantages over compressive seals because they require a relatively simple method for binding ceramic and metal parts (rather than applying an external sealing load).

Silica $\left(\mathrm{SiO}_{2}\right)$ is a basic raw material widely used in industrials. Rice Rusk (RH) can be considered as a suitable source of energy and silica in Asian countries. Given that rice production in Indonesia is quite abundant. Resulting rice husk waste is quite large with 15.8 million tons per year. Nowadays, RH has the potential to be developed into silicon-based materials that can be used for the production of 
silicon carbide, silica, silicon nitride, silicon tetrachloride, pure silicon, and zeolite [12]. Silica can be obtained in nature such as quartz sand and in living things. RH itself has a large amount of waste. Rice husk through the purification process produces RHA (Rice Husk Ash) containing high-level $\mathrm{SiO}_{2}$ [12-15]. RHA can be used as a ceramic material for various advanced applications [16]-[20].

The main objective of this research is to develop a sealing material based on RHA as a substitute for pure $\mathrm{SiO}_{2}$ derived from extracting $\mathrm{RH}$ by synthesizing other material as a reinforcement of seal performance. RHA is a product of thermochemical transformation of RH. Conditions in the conversion process (pyrolysis, gasification or combustion) affect physical-chemical characteristics of the final product. RHA generally contains approximately $60 \%$ of silica $\left(\mathrm{SiO}_{2}\right)$, $10-40 \%$ carbon and a small portion of other material compositions. The main components of $\mathrm{RH}$ are lignin, cellulose and ash which vary depending on climate, variety and geographical location where rice is planted. White ash obtained from the combustion of this raw material at moderate temperatures contains $87 \pm 97 \%$ silica in an amorphous form and a number of metal impurities such as iron $(\mathrm{Fe})$, manganese $(\mathrm{Mn})$, calcium $(\mathrm{Ca})$, sodium $(\mathrm{Na})$, potassium $(\mathrm{K})$ and magnesium $(\mathrm{Mg})$ which affects the purity and color of silica and it can be removed by pre-treatment with hydrochloric and sulfuric or nitric acid before combustion [21].

The utilization of rice husk as a source of silica is based on the removal of impurities with low effort and high specific surfaces [14,22-25]. Chen showed that sufficient pure silica can be obtained from RHA by simple acid washing procedures [21]. It has also been shown that with acid leaching, silica with purity of $>99 \%$ can be obtained by combusting rice husks at $600^{\circ} \mathrm{C}$ under normal atmospheric pressure [15],[18],[26]-[28].

The process of combusting $\mathrm{RH}$ from various experiences shows the correlation between microstructure and combustion control. The amorphous structure of the $\mathrm{SiO}_{2}$ produced provides physical information on various combustion treatments on the results [13],[29],[30]. Treatment and combustion process provides an overview of the most inexpensive process options with the most optimal quality and quantity of ceramic material [15]. It is concluded that at $600^{\circ} \mathrm{C}$ to $1000^{\circ} \mathrm{C}$, depending on the combustion time, amorphous silica is formed. However, at higher temperatures, crystalline silica is obtained.

The purpose of this study is to select the Central Java local RHA through characteristic comparisons. The properties revealed include; the determination of the structural properties of the compound, the level of $\mathrm{SiO}_{2}$ content, grain surface area, pore diameter, particle size, crystallinity level and morphological structure. This procedure serves as a preliminary determining RHA characteristics prior to combined it with other oxides to form a sealing ceramic material composition.

\section{MATERIAL AND METHOD}

\subsection{RHA Production}

IR 64 Rice Husk was obtained from several rice mills in Klaten (R1) and Wonosobo (R2) Central Java. RH was rinsed with Sodium Lauryl Sulfate (SLS) solution as a surfactant with constant stirring of 10 minutes. SLS is also known as Sodium dodecyl sulfate ( $\mathrm{C} 12 \mathrm{H} 25 \mathrm{SO} 4 \mathrm{Na}$ ), is surfactant anion. This chemical salt is organosulfur anion containing 12-carbon tails bound to sulfate groups, making this chemical substance have ambiphilic properties as a condition of a detergent. SLS is a very powerful type of surfactant used to bind oil and water-soluble impurities.

RHA production can be briefly explained as follows: First, rice husk was rinsed with distilled water to remove surfactants. After that was, the first natural drying step to eliminate moisture In the next process, $\mathrm{RH}$ was rinsed separately and treated with sulfuric acid $\mathrm{H}_{2} \mathrm{SO}_{4}$ at $\sim 60^{\circ} \mathrm{C}$ with a concentration of $0.5 \mathrm{M}$ for 30 minutes with constant stirring. The use of sulfuric acid was based on the experience of Abu et al. who used various acids in the leaching process. Next, RH was rinsed with distilled water until it was acid-free, then filtered and dried with natural heating. Rice husks that had been dried naturally were then dried further in an oven at $110^{\circ} \mathrm{C}$ for 24 hours to completely eliminate humidity. The next process was burning the furnace at $650^{\circ} \mathrm{C}$ for 2 hours to obtain white RHA selection of temperatures above $500^{\circ} \mathrm{C}$ is due to the previous experience of using lower temperatures resulted in observable carbon elements marked with black or brown color.

\subsection{RHA Characteristics}

$\mathrm{RH}$ combustion producing RHA-R1 and RHA-R2 were analyzed using various analytical tools to help characterization process. The functional groups in the sample were determined using the FTIR Thermo Nicolet Avatar 360. Particle size was measured using the Particle Size Analyzer (PSA) using the Static Light Scattering method. The spectrum was recorded with 32 scans at $4 \mathrm{~cm}-1$ resolution in the range 4000-400 cm-1. X-ray diffraction (XRD) patterns were obtained using X-ray diffraction (Bruker D2 Phaset $2^{\text {nd }}$ Gen) with $\mathrm{CuK} \alpha$ which was operated at $40 \mathrm{kV}$ and $40 \mathrm{~mA}$ and 2 Theta between $5^{\circ}$ to $50^{\circ}$. About $0.05 \mathrm{~g}$ of the sample was mixed in $10 \mathrm{~g}$ of distilled water after mixed strongly and sonicated for 30 minutes. The silica and metal impurity content in the sample was estimated with Wavelength Dispersive X-ray Fluorescence (WDXRF) - Rigaku Supermini200. Surface area and pore volume of the sample 
Gunawan et al., International Journal of Emerging Trends in Engineering Research, 8(7), July 2020, 4812 - 4818

were measured using Brunauer-Emmett-Teller (BET) Surface Area Analysis and / or Barrett-Joyner-Halenda (BJH) Pore Size and Pore Volume Analysis (Equipment / Method: Gas Sorption / Physisorption by Quantachrome Instruments).

BET analysis provides an evaluation of specific surface area of the material by utilizing multilayer nitrogen adsorption measured as a relative pressure function using a fully automatic analyzer. This technique involves evaluating the external area and pore area to determine the total specific surface area in $\mathrm{m}^{2} / \mathrm{g}$, producing important information in studying the effects of surface porosity and particle size in many applications. BJH analysis can also be used to determine pore area and specific pore volume using adsorption and desorption techniques. This technique characterizes the pore size distribution independent from external area due to the particle size of the sample.

Scanning Electron Microscope (SEM) is a type of electron microscope capable of producing high-resolution images of a sample surface. This microscope is used to study the surface structure of objects, which are generally magnified between 1,000-40,000 times. Through analysis using SEM, it is expected to be able to observe the morphological characteristics of the particles produced.

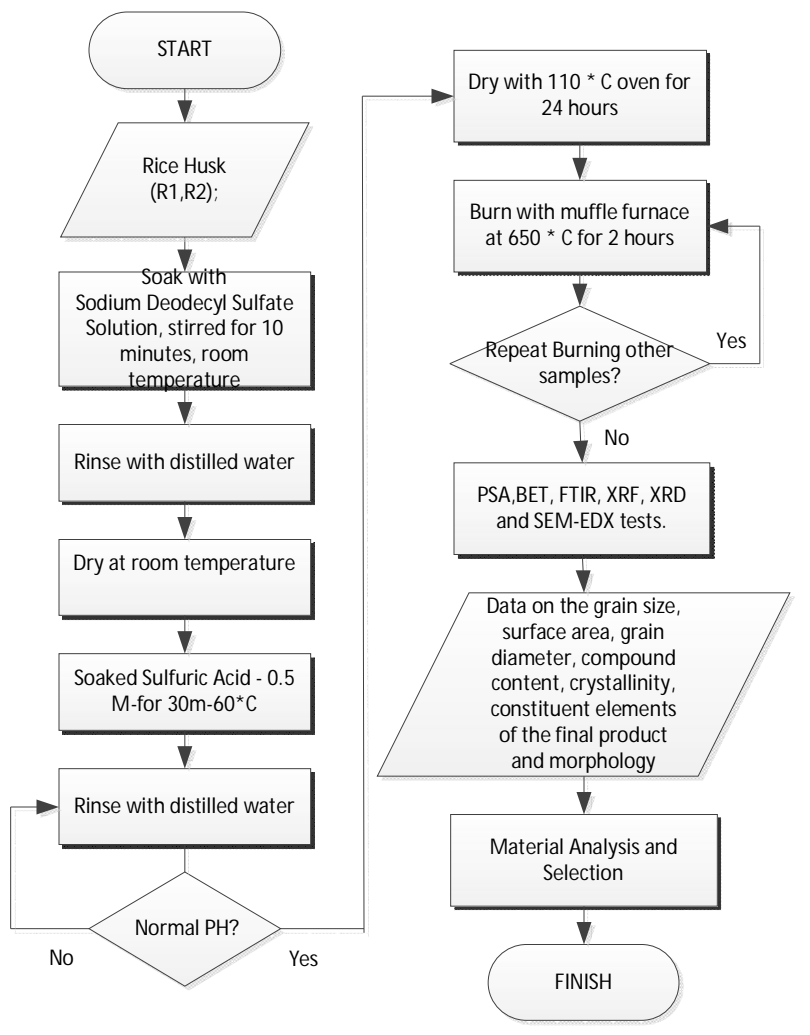

Figure 1: Production process flow and characterization
Table 1: Typical group uptake functions on RHA-R1

\begin{tabular}{|l|l|l|}
\hline $\begin{array}{l}\text { Wave } \\
\text { Number } \\
\left(\mathbf{c m}^{-\mathbf{1}}\right)\end{array}$ & Group & Compound \\
\hline 3478 & $\mathrm{NH}$ & Amina Primer \\
\hline 2363 & $\mathrm{C}=\mathrm{C}$ & Alkuna \\
\hline 1635 & $\mathrm{C}=\mathrm{C}$ & Alkena \\
\hline 1098 & $\mathrm{C}-\mathrm{O}-\mathrm{C}$ & Eter \\
\hline 802 & $-(\mathrm{CH} 2) n$ & Other \\
\hline 465 & $-(\mathrm{CH} 2) \mathrm{n}$ & Other \\
\hline
\end{tabular}

Further reading on ceramics, its wear characteristics and the surface treatment can be found in [31], [32] and [33].

\section{RESULT AND DISCUSSION}

\subsection{Fourier Transform Infrared (FTIR) Analysis}

The FTIR spectra of silica immersed in sulfuric acid after combustion at $650^{\circ} \mathrm{C}$ are shown in Figure 2. The main absorption peak at $1098 \mathrm{~cm}^{-1}, 465 \mathrm{~cm}^{-1}, 3478 \mathrm{~cm}^{-1}, 802 \mathrm{~cm}^{-1}$, $1635 \mathrm{~cm}^{-1}, 2363 \mathrm{~cm}^{-1}$ and R2 $=1098 \mathrm{~cm}^{-1}, 464 \mathrm{~cm}^{-1}, 3465$ $\mathrm{cm}^{-1}, 802 \mathrm{~cm}^{-1}, 1638 \mathrm{~cm}^{-1}$ in Figure 3 as an attribute for $\mathrm{O}-\mathrm{Si}-\mathrm{O}$ stretching and bending vibrations.

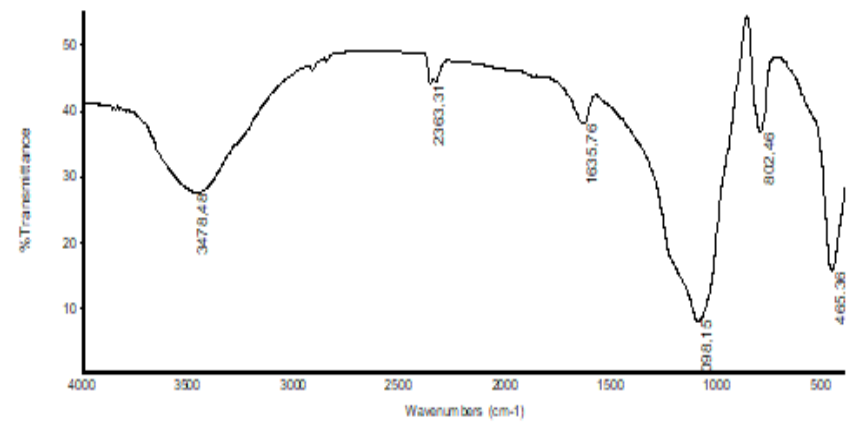

Figure 2: FTIR analysis for sample R1

Table 2: Typical group uptake functions on RHA-R2

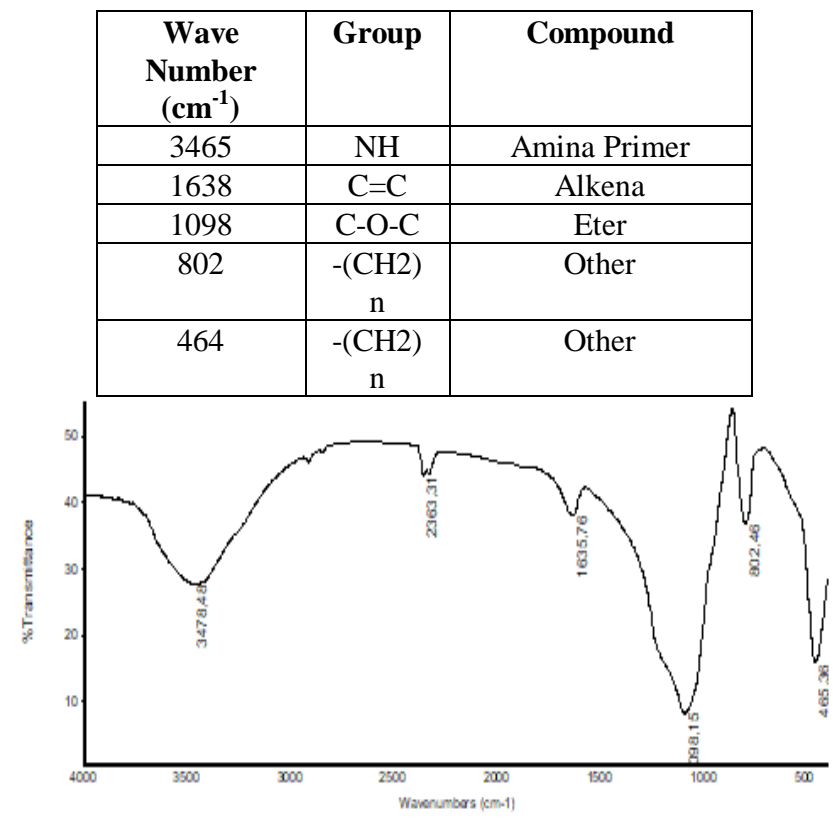

Figure 3: FTIR analysis for sample R2 
Table 3: Particle size

\begin{tabular}{|c|c|c|}
\hline \multirow{2}{*}{$\begin{array}{c}\text { Static Light Scattering) } \\
\text { using PSA }\end{array}$} & \multicolumn{2}{|c|}{$\mu \mathrm{m}$} \\
\cline { 2 - 3 } & 265.93 & $\mathrm{R} 2$ \\
\hline S1 & 274.7 & 216.3 \\
\hline S2 & 263.38 & 221.52 \\
\hline S3 & 268.00 & 217.47 \\
\hline
\end{tabular}

\subsection{Fourier Transform Infrared (FTIR) Analysis}

The particle size of silica at various combustion temperatures is given in Table 3. It was measured by PSA using the Static Light Scattering method with results varying from $214 \mu \mathrm{m}$ to $275 \mu \mathrm{m}$.

\subsection{Characterization of Crystallinity}

The XRD pattern of insoluble silica at combustion temperatures is shown in Figure 3 and Figure 4, respectively. The XRD pattern of the two silica materials shows the same pattern as leached sulfuric acid. A wide-spread peak with maximum intensity at $2 \theta=22 \mathrm{o}$ was observed, indicating the amorphous nature of silica. Silica released by acid showed a truly amorphous structure after combustion below $900^{\circ} \mathrm{C}$, after which there was an increase in crystallinity [15]. This is due to the removal of alkali metals during acid leaching which inhibits the eutectic reaction with silica. Therefore, optimization of the combustion temperature of rice husk is needed to inhibit the crystallization of silica.

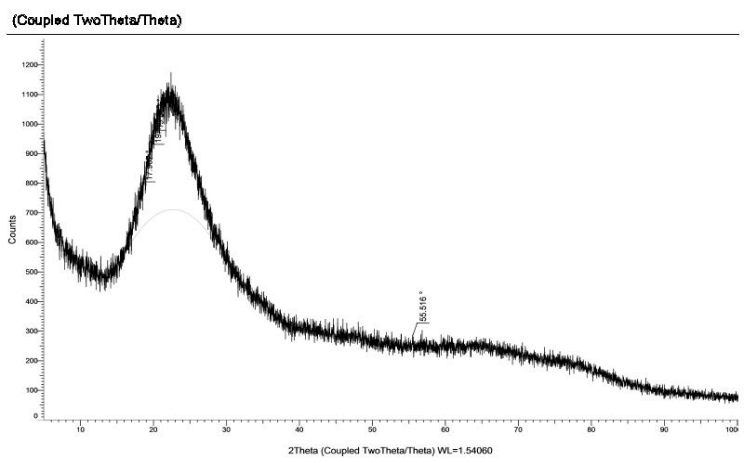

(a)

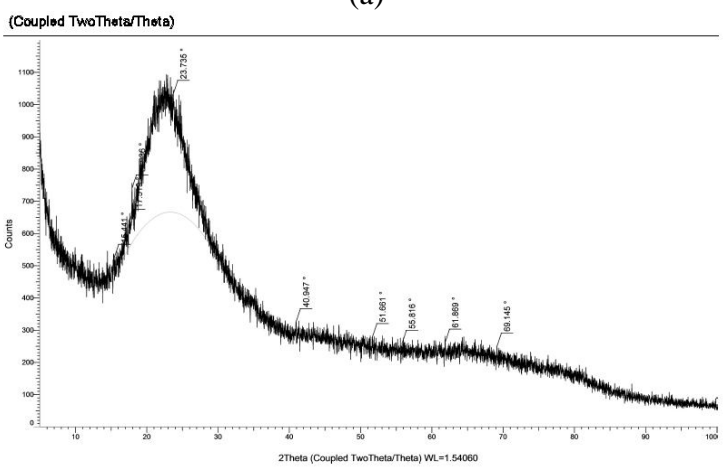

(b)

Figure 4: (a) Spectrum of X-Ray RHA-R1, (b) Spectrum of X-Ray RHA-R2

\subsection{Analysis of XRF}

XRF was used in identifying the chemical composition and purity of silica produced from rice husks. The silica production process at $\mathrm{R} 1$ reached $97.27 \%$ which was higher than $\mathrm{R} 2$ which was $97.03 \%$. It needs to be emphasized here that the route chosen in getting $\mathrm{SiO}_{2}$ was quite effective in removing metal impurities in rice husks. Table 4 shows that silica $\left(\mathrm{SiO}_{2}\right)$ is the main component and also contains a low amount of metal impurity.

Some $\mathrm{Al}_{2} \mathrm{O}_{3}, \mathrm{CaO}$ compound was identified as oxides reinforcing SOFC sealing ceramic characters, so the presence of these oxides can be considered not as impurities.

Table 4: Chemical Composition

\begin{tabular}{|c|c|c|c|c|c|}
\hline Content & $\mathbf{S i O}_{\mathbf{2}}$ & $\begin{array}{c}\mathbf{A l}_{2} \mathbf{O} \\
\mathbf{7}\end{array}$ & $\mathbf{P}_{\mathbf{2}} \mathbf{O}_{\mathbf{5}}$ & $\mathbf{S O}_{\mathbf{3}}$ & $\mathbf{K}_{\mathbf{2}} \mathbf{O}$ \\
\hline \multicolumn{7}{|c|}{ mass\% } \\
\hline $\mathrm{R} 1$ & 97.27 & - & 0.68 & 0.14 & 0.48 \\
\hline $\mathrm{R} 2$ & 97.03 & 0.08 & 1.20 & 0.10 & 0.84 \\
\hline Content & $\mathbf{C a O}$ & $\mathbf{M n O}$ & $\begin{array}{c}\mathbf{F e}_{2} \mathbf{O} \\
\mathbf{3}\end{array}$ & $\mathbf{R u O}_{\mathbf{2}}$ & $\mathbf{A g}_{\mathbf{2}} \mathbf{O}$ \\
\hline \multicolumn{7}{|c|}{ mass\% } \\
\hline $\mathrm{R} 1$ & 0.68 & 0.15 & 0.23 & 0.11 & 0.26 \\
\hline $\mathrm{R} 2$ & 0.56 & 0.09 & 0.08 & - & - \\
\hline
\end{tabular}

\subsection{Analysis of BET-BJH}

Ideally, a porous material should have a pore size distribution that depends on a particular application. In addition, it must exhibit high chemical properties, thermal, hydrothermal and mechanical stability, with high surface area and large pore size. This material must have a specific particle size which is around $1-100 \mathrm{~nm}$. The porous material is initially defined according to its adsorption properties. Based on this, porous material is distinguished by its porous size. Mesoporous material is a material that has an average diameter of its axis between 2-50 $\mathrm{nm}$ which refers to the IUPAC classification. According to IUPAC, a porous material is divided into three classifications, namely micropores having shaft diameters of less than $2 \mathrm{~nm}$, mesopores having shaft diameters between $2-50 \mathrm{~nm}$, and macropores having shaft diameters of more than $50 \mathrm{~nm}$.

Table 5: Result of BET-BJH Test

\begin{tabular}{|l|l|c|c|}
\hline Surface Area Results & unit & \multicolumn{1}{c|}{ R1 } & \multicolumn{1}{c|}{ R2 } \\
\hline Multipoint BET & $\mathrm{m}^{2} / \mathrm{g}$ & 265.74 & 294.38 \\
\hline BJH adsorption & $\mathrm{m}^{2} / \mathrm{g}$ & 128.09 & 123.72 \\
\hline BJH desorption & $\mathrm{m}^{2} / \mathrm{g}$ & 164.49 & 159.63 \\
\hline Pore Volume Results & & & \\
\hline BJH adsorption cumulative & $\mathrm{cc} / \mathrm{g}$ & 0.22 & 0.21 \\
\hline
\end{tabular}


Gunawan et al., International Journal of Emerging Trends in Engineering Research, 8(7), July 2020,4812 - 4818

\begin{tabular}{|l|l|r|r|}
\hline micropore volume & & & \\
\hline $\begin{array}{l}\text { BJH desorption cumulative } \\
\text { micropore volume }\end{array}$ & $\mathrm{cc} / \mathrm{g}$ & 0.24 & 0.23 \\
\hline Total Pore Volume & $\mathrm{cc} / \mathrm{g}$ & 0.27 & 0.28 \\
\hline Pore Size Results & & & \\
\hline BJH adsorption pore radius & $\mathrm{nm}$ & 1.64 & 1.64 \\
\hline BJH desorption pore radius & $\mathrm{nm}$ & 1.85 & 1.85 \\
\hline Average Pore Size & $\mathrm{nm}$ & 2.04 & 1.89 \\
\hline
\end{tabular}

Surface area, pore volume and pore diameter of silica are given in Table 3. Surface Area reached R1 $265.74 \mathrm{~m}^{2} / \mathrm{g}$ and $\mathrm{R} 2294.38 \mathrm{~m}^{2} / \mathrm{g}$. The granular surface area and pore volume of sample R2 is greater than R1. This shows that the source of rice husk has variations, one of which is the origin. The high porous structure was obtained as confirmation by Pore R1 volume $0.27 \mathrm{cc} / \mathrm{g}$ and $\mathrm{R} 20.28 \mathrm{cc} / \mathrm{g}$. The average pore diameter of R1 is $~ 2.04 \mathrm{~nm}$ and $\mathrm{R} 2$ is $1.89 \mathrm{~nm}$, indicating that the silica produced by $\mathrm{R} 1$ is mesoporous and $\mathrm{R} 2$ is micropore. It should be noted that hydrochloric acid or sulfuric acid has significantly increased surface area and pore volume, and reduced pore diameter.

\subsection{Characterization of RHA : SEM-EDX Silica}

SEM-EDX analysis using Scanning Electron Microscopy (SEM) was used by the Phenom Pro $\mathrm{X}$ brand, displaying morphological images as shown in Figure 5 and Figure 6.

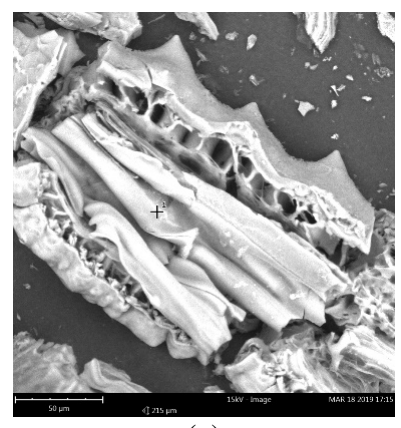

(a)

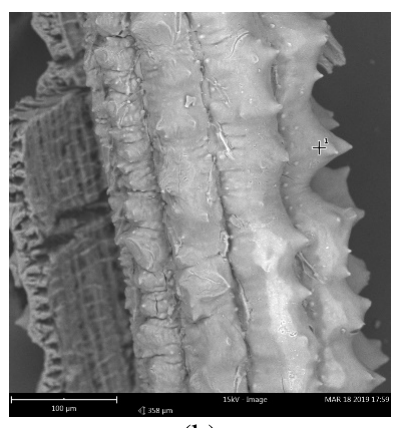

(b)
Figure 5: (a) The Morphology and Size of Silica at R1 and (b) R2 on the Field of View $215 \mu \mathrm{m}$,

Mode: $15 \mathrm{kV}$ - Image, Detector: BSD Full

Table 6: The Composition of Elements and R1 Oxide through EDX

\begin{tabular}{|c|c|c|c|c|}
\hline $\begin{array}{c}\text { Element } \\
\text { Symbol }\end{array}$ & $\begin{array}{c}\text { Atomic } \\
\text { Conc. }\end{array}$ & $\begin{array}{c}\text { Weight } \\
\text { Conc. }\end{array}$ & $\begin{array}{c}\text { Oxide } \\
\text { Symbol }\end{array}$ & $\begin{array}{c}\text { Stoich. } \\
\text { wt Conc. }\end{array}$ \\
\hline $\mathrm{Si}$ & 35.01 & 51.68 & $\mathrm{Si}$ & 73.06 \\
\hline $\mathrm{O}$ & 34.80 & 29.26 & & \\
\hline $\mathrm{C}$ & 30.19 & 19.06 & $\mathrm{C}$ & 26.94 \\
\hline
\end{tabular}

SEM results from the sample were taken with a size of 1 micron in 1 micron which equals 1000 nano and from the results of specimens that used 28,000 cycles speed results in nano size i.e. $215 \mu \mathrm{m}$. So the percentage of elements $\mathrm{Si}$ $35.01 \%$ and $\mathrm{O}$ as much as $24.80 \%$ which formed $\mathrm{SiO}_{2}$ oxide compounds as much as $73.06 \%$.
Table 7: The Composition of Elements and Oxide R2 through EDX

\begin{tabular}{|c|c|c|c|c|}
\hline $\begin{array}{c}\text { Element } \\
\text { Symbol }\end{array}$ & $\begin{array}{c}\text { Atomic } \\
\text { Conc. }\end{array}$ & $\begin{array}{c}\text { Weight } \\
\text { Conc. }\end{array}$ & $\begin{array}{c}\text { Oxide } \\
\text { Symbol }\end{array}$ & $\begin{array}{c}\text { Stoich. } \\
\text { wt Conc. }\end{array}$ \\
\hline $\mathrm{O}$ & 75.22 & 67.74 & & \\
\hline $\mathrm{Si}$ & 16.79 & 26.55 & $\mathrm{Si}$ & 82.28 \\
\hline $\mathrm{C}$ & 5.20 & 3.51 & $\mathrm{C}$ & 10.89 \\
\hline $\mathrm{N}$ & 2.79 & 2.20 & $\mathrm{~N}$ & 6.83 \\
\hline
\end{tabular}

From the SEM images, the samples were taken with a size of 1 micron where 1 micron equals to 1000 nano, and from the results of specimens using 140,000 cycles speed obtained nano size result i.e. $358 \mu \mathrm{m}$. So, the percentage of $\mathrm{Si}$ elements $16.79 \%$ and $\mathrm{O}$ as much as $75.22 \%$ which formed $\mathrm{SiO}_{2}$ oxide compounds as much as $82.28 \%$

\section{CONCLUSION}

Based on the analysis of the husk ash sample by calcination route using sulfuric acid leaching with controlled combustion at $650^{\circ} \mathrm{C}$ for 2 hours, the $\mathrm{SiO}_{2}$ content at $\mathrm{R} 1$ reached $97.27 \%$ and R2 obtained $97.03 \%$ with a number of distributed impurities. The characterization of rice husk ash from both samples produced amorphous silica $\mathrm{SiO}_{2}$ and the average particle size was in the range of $\mathrm{R} 1=0.217$ and $\mathrm{R} 2=0.268$ $\mu \mathrm{m}$. The surface area of silica grains produced after washing rice husk with sulfuric acid R1 $=265.73 \mathrm{~m}^{2} / \mathrm{g} \mathrm{R} 2=, 294.37$ $\mathrm{m}^{2} / \mathrm{g}$. The average pore diameter of $\mathrm{R} 1$ is $\sim 2.04 \mathrm{~nm}$ and $\mathrm{R} 2$ is $1.89 \mathrm{~nm}$, indicating that the silica produced by $\mathrm{R} 1$ is mesoporous and R2 is micropore. Amorphous silica with high purity has a large granular surface area, useful as an absorber or supporting catalyst in fine chemical synthesis, especially oxide character booster in its preparation as a seal on the SOFC system.

\section{ACKNOWLEDGEMENT}

The author would like to thank to the Indonesian Ministry of Research and Technology and Higher Education and LPPM UNISSULA for this research grant.

\section{REFERENCES}

1. M. Frank, R. Deja, R. Peters, L. Blum, and D. Stolten. Bypassing renewable variability with a reversible solid oxide cell plant, Applied energy, vol. 217, pp. 101-112, 2018.

2. K. C. Wincewicz, and J. S. Cooper. Taxonomies of SOFC material and manufacturing alternatives, Journal of Power Source, vol. 140, no. 2, pp. 280-296, 2004.

3. L. Luo, Y. Lin, Z. Huang, Y. Wu, L. Sun, L. Cheng, and J. Shi. Application of BaO-CaO-Al2O3-B2O3-SiO2 glass-ceramic seals in large size planar IT-SOFC, Ceramics International, vol. 41, no. 8, pp. 9239-9243, 2015.

4. S. F. Wang, Y. F. Hsu, and Y. C. Hsieh. Effects of $\mathrm{La2O3}, \mathrm{Nd2O3}, \mathrm{NiO}$ and $\mathrm{CoO}$ additions on the 
characteristics of $\mathrm{SiO2}-\mathrm{Al} 2 \mathrm{O3}-\mathrm{Y} 2 \mathrm{O3}-\mathrm{ZnO}$ glass seals for intermediate temperature solid oxide fuel cells, International Journal of Hydrogen Energy, vol. 40, no. 8, pp. 3338-3347, 2015.

5. M. J. Da Silva, J. F. Bartolomé, H. Antonio, and S. Mello-Castanho. Glass ceramic sealants belonging to BAS (BaO-Al2O3-SiO2) ternary system modified with B2O3 addition: A different approach to access the SOFC seal issue, Journal of the European Ceramic Society, vol. 36, no. 3, pp. 631-644, 2016.

6. J. Partyka, and M. Leśniak. Preparation of glass-ceramic glazes in the SiO2-Al2O3-CaO-MgO-K2O-Na2O-ZnO system by variable content of $\mathbf{Z n O}$, Ceramics International, vol. 42, no. 7, pp. 8513-8524, 2016.

7. B. Li, W. Li, and J. Zheng. Effect of SiO2 content on the sintering kinetics, microstructures and properties of $\mathrm{BaO}-\mathrm{Al} 2 \mathrm{O3}-\mathrm{B} 2 \mathrm{O3}-\mathrm{SiO} 2$ glass-ceramics for LTCC application, Journal of Alloys and Compounds, vol. 725, pp. 1091-1097, 2017.

8. S. F. Wang, H. C. Lu, Y. X. Liu, Y. F. Hsu, and Z. Y. Liu. Characteristics of glass sealants for intermediate-temperature solid oxide fuel cell applications, Ceramics International, vol. 43, pp. S613-S620, 2017, 2017.

9. X. Wang, R. Li, J. Yang, D. Gu, D. Yan, J. Pu, and J. Li. Effect of YSZ addition on the performance of glass-ceramic seals for intermediate temperature solid oxide fuel cell application, International Journal of Hydrogen Energy, vol. 43, no. 16, pp. 8040-8047, 2018.

10. Sulistyo, S. Mahzan, and S. Ariffin. Mechanical Properties of Clay Thin Plate as Pre $\square$ Evaluation for Solid Oxide Fuel Cell Manufacture, In AIP Conference Proceedings, vol. 1169, no. 1, pp. 87-92, September 2009.

11. N. Mahato, A. Banerjee, A. Gupta, S. Omar, and K. Balani. Progress in material selection for solid oxide fuel cell technology: A review, Progress in Materials Science, vol. 72, pp. 141-337, 2015.

12. D. An, Y. Guo, Y. Zhu, and Z. Wang. A green route to preparation of silica powders with rice husk ash and waste gas, Chemical Engineering Journal, vol. 162, no. 2, pp. 509-514, 2010.

13. V. B. Carmona, R. M. Oliveira, W. T. L. Silva, L. H. C. Mattoso and J. M. Marconcini. Nanosilica from rice husk: extraction and characterization, Industrial Crops and Products, vol. 43, pp. 291-296, 2013.

14. Y. Shen, P. Zhao, and Q. Shao. Porous silica and carbon derived materials from rice husk pyrolysis char, Microporous and Mesoporous Materials, vol. 188, pp. 46-76, 2014.

15. R. A. Bakar, R. Yahya, and S. N. Gan. Production of high purity amorphous silica from rice husk, Procedia Chemistry, vol. 19, pp. 189-195, 2016.

16. M. M. Haslinawati, K. A. Matori, Z. A. Wahab, H. A. A. Sidek, and A. T. Zainal. Effect of temperature on ceramic from rice husk ash, Int. J. Basic Appl. Sci, vol. 9, no. 9, pp. 111-117, 2009.

17. E. J. Siqueira, I. V. P. Yoshida, L. C. Pardini, and M. A. Schiavon. Preparation and characterization of ceramic composites derived from rice husk ash and polysiloxane, Ceramics International, vol. 35, no. 1, pp. 213-220, 2009.

18. J. P. Nayak, and J. Bera. Phase Transitions: A Multinational Effect of sintering temperature on phase-formation behavior and mechanical properties of silica ceramics prepared from rice husk ash, pp. 37-41, 2010.

19. J. P. Nayak, S. Kumar, and J. Bera. Sol-gel synthesis of bioglass-ceramics using rice husk ash as a source for silica and its characterization, Journal of Non-Crystalline Solids, vol. 356, no. 28-30, pp. 1447-1451, 2010.

20. Y. Shen. Rice husk silica derived nanomaterials for sustainable applications, Renewable and Sustainable Energy Reviews, vol. 80, pp. 453-466.

21. J. M. Chen, and F. W. Chang. The chlorination kinetics of rice husk, Industrial \& engineering chemistry research, vol. 30, no. 10, pp. 2241-2247, 2017.

22. S. Rukzon, P. Chindaprasirt, and R. Mahachai. Effect of grinding on chemical and physical properties of rice husk ash, International Journal of Minerals, Metallurgy and Materials, vol. 16, no. 2, pp. 242-247, 2009.

23. T. H. Liou, and C. C. Yang. Synthesis and surface characteristics of nanosilica produced from alkali-extracted rice husk ash, Materials science and engineering: $B$, vol. 176, no. 7, pp. 521-529, 2011. https://doi.org/10.1016/j.mseb.2011.01.007

24. L. Muniandy, F. Adam, A. R. Mohamed, and E. P. Ng. The synthesis and characterization of high purity mixed microporous/mesoporous activated carbon from rice husk using chemical activation with $\mathrm{NaOH}$ and KOH, Microporous and Mesoporous Materials, vol. 197, pp. 316-323, 2014.

25. Y. V. Larichev, P. M. Yeletsky, and V. A. Yakovlev. Study of silica templates in the rice husk and the carbon-silica nanocomposites produced from rice husk, Journal of Physics and Chemistry of Solids, vol. 87, pp. 8-63, 2015.

26. N. Yalcin, and V. Sevinc. (2001). Studies on silica obtained from rice husk. Ceramics international, vol. 27, no. 2, pp. 219-224, 2001.

27. F. Adam, J. N. Appaturi, and A. Iqbal. The utilization of rice husk silica as a catalyst: review and recent progress, Catalysis Today, vol. 190, no. 1, pp. 2-14, 2012.

28. M. Azadeh, C. Zamani, A. Ataie, and J. R. Morante. Three-dimensional rice husk-originated mesoporous silicon and its electrical properties, Materials Today Communications, vol. 14, pp. 141-150, 2018.

29. J. Umeda, and K. Kondoh. High-purification of amorphous silica originated from rice husks by combination of polysaccharide hydrolysis and 
metallic impurities removal, Industrial crops and products, vol. 32, no. 3, pp. 539-544, 2010.

30. U. Zulfiqar, T. Subhani, and S. W. Husain. Towards tunable size of silica particles from rice husk, Journal of Non-Crystalline Solids, vol. 429, pp. 61-69, 2015.

31. Ivanov, V.A. Reconditioning of worn process equipment using composite materials, International Journal of Emerging Trends in Engineering Research 8(6),68, pp. 2635-2642, 2020.

https://doi.org/10.30534/ijeter/2020/68862020

32. Ivanov, V.A. Wear resistance of repair composite materials with ceramic fillers, International Journal of Emerging Trends in Engineering Research 8(4),39, pp. 1192-1195, 2020.

https://doi.org/10.30534/ijeter/2020/39842020

33. Darmawan, A.S., Siswanto, W.A., Sujitno, T. Comparison of commercially pure titanium surface hardness improvement by plasma nitrocarburizing and ion implantation, Advanced Materials Research, 789, pp. 347-351, 2013. 